\title{
Memory and intellectual styles: Performance of students with learning disabilities
}

\author{
Memória e estilos intelectuais: desempenho de \\ alunos com dificuldade para aprender
}

\author{
Francislaine Flâmia INÁCIO' \\ ORCID iD 0000-0001-5727-7324 \\ Katya Luciane de OLIVEIRA ${ }^{2}$ \\ ORCID iD 0000-0002-2030-500X \\ Acácia Aparecida Angeli dos SANTOS 3 \\ ORCID iD 0000-0002-8599-7465
}

\begin{abstract}
Studies addressing issues related to information processing are necessary to understand some of the explanatory aspects of the changes in the learning process. The objective of the this study was to evaluate memory and intellectual styles in Elementary and Middle school students diagnosed with dyslexia and Attention Deficit Hyperactivity Disorder and in students without learning disabilities. A total of 370 students from public schools were individually evaluated using the Rey Complex Figure Test and the Thinking Styles Inventory - Revised II. The results showed significant differences in the memory condition between students with Attention Deficit Hyperactivity Disorder and those without learning disabilities. Significant differences in the scores of the Thinking Styles Inventory were also found between the three groups evaluated. Memory was negatively correlated with the conservative style. The difference between the groups and the correlation between these instruments pointed to the need for further research to assess these variables in the groups of students with learning disabilities.
\end{abstract}

Keywords: Attention deficit disorder with hyperactivity; Cognitive psychology; Dyslexia; Educational evaluation; Elementary educational.

\section{Resumo}

O estudo sobre as questões relacionadas ao processamento da informação se faz necessário para entender alguns dos aspectos explicativos das alterações na aprendizagem. O objetivo da pesquisa foi avaliar a memória e os estilos intelectuais

1 Universidade Estadual de Londrina, Centro de Educação, Comunicação e Artes, Programa de Pós-Graduação em Educação. Londrina, PR, Brasil.

2 Universidade Estadual de Londrina, Centro de Ciências Biológicas, Departamento de Psicologia e Psicanálise Londrina. Rod. Celso Garcia Cid, s/n., PR 445, km 380, Campus Universitário, 86057-970, Londrina, PR, Brasil. Correspondência para/Correspondence to: K.L. OLIVEIRA. E-mail: <katyauel@gmail.com>.

3 Universidade São Francisco, Faculdade de Psicologia, Programa de Pós-Graduação Stricto Sensu em Psicologia. Itatiba, SP, Brasil. Article based on the master's thesis of F.F. INÁCIO, entitled "Memória, estilos intelectuais e estratégias de aprendizagem: estudando os transtornos do neurodesenvolvimento em alunos do ensino fundamental e percepção de seus professores". Universidade Estadual de Londrina, 2016.

Support: Conselho Nacional de Desenvolvimento Científico e Tecnológico (PPEDU/UEL n. 002/2014).

$\boldsymbol{\nabla} \mathbf{\nabla} \boldsymbol{\nabla}$

Como citar este artigo/How to cite this article

Inácio, F. F., Oliveira, K. L., \& Santos, A. A. A. (2018). Memory and intellectual styles: Performance of students with learning disabilities. Estudos de Psicologia (Campinas), 35(1), 65-75. https://doi.org/10.1590/1982-02752018000100007 
nos alunos do ensino fundamental com diagnóstico de dislexia e transtorno de déficit de atenção/hiperatividade e sem dificuldade escolar. Foram avaliados, individualmente, 370 alunos de escolas públicas. Utilizou-se o teste Figuras Complexas de Rey e o Inventário de Estilos Intelectuais - Revisado II. Os resultados apontaram diferenças significativas entre os alunos com transtorno de déficit de atenção/hiperatividade e sem dificuldade escolar no item memória. No inventário de estilos houve diferenças significativas entre os três grupos. A memória apresentou correlação negativa com o estilo conservador. A diferença entre os grupos e a correlação entre os instrumentos apontaram para a necessidade de pensar em pesquisas que avaliem essas variáveis nos grupos com diagnóstico.

Palavras-chave: Transtorno de falta de atenção com hiperatividade; Psicologia cognitive; Dislexia; Avaliação educacional; Ensino fundamental.

Learning is the result of functional and neurochemical changes that lead to modifications in the National Health Council learning behavior involves the interaction of intrinsic and extrinsic factors. The intrinsic factors can be divided into primary and secondary categories. Primary or specific difficulties are defined by discrepancy between academic achievement and intellectual ability that is not due to changes in sensory or psychological factors. Secondary difficulties initially affect the normal human development, and later they impact learning. On the other hand, the extrinsic factors are related to the difficulties encountered by individuals at some point throughout the school years, which tend to disappear due to student efforts or changes in teaching methodology (Carvalho et al., 2016; Moojen \& Costa, 2016; Ohlweiler, 2016; Rotta, 2016).

Primary intrinsic factors include Specific Learning Disorder and Attention Deficit Hyperactivity Disorder (ADHD). According to the Diagnostic and Statistical Manual of Mental Disorders ( $5^{\text {th }}$ edition, American Psychiatric Association [APA], 2014), these disorders are related to neurodevelopmental disorders and indicate changes that take place in the early stages of development and affect the personal, social, academic, and professional.

Specific Learning Disorder is related to persistent difficulties in learning basic academic skills of reading, writing, and mathematics. Thus, it is subdivided based on skills, and the skill related to trouble reading is commonly known as Dyslexia or Developmental Dyslexia (APA, 2014). Dyslexia is characterized as a severe impairment in the development of word recognition skills, letter decoding, and reading comprehension, leading 66 to phonological processing and memory problems
(Fletcher, Lyons, Fuchs, \& Barnes, 2009; Moojen \& França, 2016; Rotta \& Pedroso, 2016).

Attention Deficit Hyperactivity Disorder is characterized by difficulty in following through on tasks, disorganization, excessive motor activity and talking, restlessness, intrusion, and difficulty awaiting one's turn. These symptoms affect the individual functioning and development. This disorder is divided into three subtypes: predominantly inattentive, predominantly hyperactive/impulsive, and combined types (Cypel, 2016; Guardiola, 2016; Kaefer, 2016; Pisacco, Sperafico, Costa, \& Dorneles, 2016).

Cognitive deficits in students with dyslexia and ADHD lead to difficulties in the learning process. The present study addresses the importance of understanding how information processing occurs, as well as the characterization of the information processing profile of students who have these disorders. It seeks to whether there is a weaken memory performance hindering information processing between the group of students diagnosed or whether those students use intellectual styles that can promote learning. The knowledge of the memory and intellectual styles of those groups is essential to better understand them since, as discussed below, there are conflicting reports in the literature concerning this issue.

\section{Memory}

Memory is the ability to draw on past experiences to use this information in the present. Thus, it can be defined as a process of encoding (information input), storage (information storage), 
and retrieval (information output). In the classical model of information processing, memory is referred as a sequence of three storage stages: sensory memory, short term memory, and long term memory (Sternberg, 2010). In addition to the types of memory storage of the traditional model, Baddeley and Hitch (1974) proposed another memory component related to the handling of information, known as working memory.

Sensory memory refers to the selection of information by means of perception, and short-term memory, in addition to receiving the information selected, it also analyzes the information for storage in the long-term memory (Bzuneck \& Guimarães, 2010; Sternberg, 2010). Working memory has the role of detecting both known and unknown information and managing all other memories (Riesgo, 2016).

Some studies (Borkowska et al., 2011; Duranovic, Dedeic, \& Gavrić, 2015; Vélez-VanMeerbeke et al., 2013) have reported that students with dyslexia and ADHD may experience changes in memory. According to Duranovic et al. (2015), children with dyslexia had problems with immediate memory recall, whereas in the copy condition, their performance was similar to that of the control group. However, there are conflicting results since some authors found that performance of dyslexic groups was comparable to that of groups without this disorder (Brunswick, Martin \& Marzano, 2010; Cruz-Rodrigues, Barbosa, Toledo-Piza, Miranda, \& Bueno, 2014; McManus et al., 2010).

In studies using the Rey Complex Figure Test with individuals with ADHD, Mesquita, Coutinho, and Mattos (2010) found no significant differences between groups with ADHD and the control group. However, Borkowska et al. (2011) reported that children aged 6-12 years with ADHD showed poorer performance only on memory recall when compared to the control group. Similarly, Vélez-VanMeerbeke et al. (2013) found significant differences between groups with ADHD and the control group, and the groups with ADHD showed deficits in the conditions copy and immediate memory recall.
Alves and Ribeiro (2011) evaluated the auditory and visual immediate memory in elementary school students and found that performance on the memory condition improved with age and school grade. Similar results were found by Hall, Jarrold, Towse, and Zarandi (2015), who concluded that the children's working memory capacity increased with age.

Memory assessment instruments are useful to professionals because they allow verifying the organization of mental operations in the learning process, which involves the encoding and retrieval of information (Menezes, Godoy, \& Seabra, 2009). Learning requires a complex network of cognitive abilities that interact simultaneously. However, at the time of learning, every student shows a specific information processing pattern for the acquisition of knowledge, which will be discussed below (Litzinger, Ha Lee, Wise, \& Felder, 2007; Sternberg, 2010)

\section{Intellectual styles}

The model proposed by Zhang and Sternberg (2005), the Theory of Mental Self-Government, is considered the most complete model. It introduced the term "intellectual styles" as an umbrella term for all existing style constructs. Using "forms of government" metaphorically, the theory addresses how mental self-government takes place (Zhang \& Sternberg, 2005; Zhang, Sternberg, \& Rayner, 2011).

The styles were organized into five dimensions of self-government, each representing the forms of government and mental self-government. The dimensions are organized into three functions (legislative, executive, and judicial styles), four forms (monarchic, hierarchical, oligarchic, anarchic styles), two levels (global and local styles), two directions or trends (liberal and conservative styles), and two scopes (internal and external styles) (Fan \& Zhang, 2014; Zhang \& Sternberg, 2005; Zhang et al., 2011).

The styles can also be organized into three types: Types I, II, and III. Type I includes 
the: legislative, judicial, global, hierarchical, and liberal styles; Type II: executive, conservative, local, and monarchic styles; and Type III: oligarchic, anarchic, internal, and external styles. This model refers to the characteristics of each style. Type I is related to creativity, cognitive complexity, and favorable personality traits. Type II denotes low levels of cognitive complexity and includes unfavorable personality traits. Type III manifests the characteristics of the styles from both Type I and Type II depending on the preference of the individual for a particular activity (Fan \& Zhang, 2014; Zhang \& Sternberg, 2005; Zhang et al., 2011).

Martínez and Brufau (2010) highlighted that the intellectual styles are related to the organization of thoughts, and the most common styles are the monarchic, hierarchical, oligarchic, and anarchic styles. Schools usually favor students who have a preference for the executive style, i.e., students who do exactly what is asked. Some studies (Grigorenko \& Sternberg, 1995; Zhang, 2002) have shown the relationship between the legislative, judicial, and liberal styles and high intellectual abilities, and they indicated that the judicial style as the most conducive to cognitive development, as opposed to the executive style.

John, Singh, and Verma (2011) showed that the hierarchical and local styles are associated with better academic achievement as compared to the legislative, monarchic, anarchic, and global styles. Similarly, the findings of Zhang (2015) showed the superiority of Type I styles over Type II styles. In a previous study, Zhang (2010) found that Type I styles positively contributed to psychosocial development, whereas type II styles, specially the monarchic and conservative styles, negatively contributed to psychosocial development.

Promoting the intellectual styles through training programs has proved to be important not only for students, but also for the whole school team (Zhang, 2013; Zhang \& Sternberg, 2006). In order for this to occur, more studies are needed to better understand the processing profile of each student. Therefore, understanding students' information processing can be useful to overcome aimed to evaluate memory and intellectual styles in elementary and middle school students with dyslexia and Attention deficit hyperactivity disorder and in students without learning disabilities.

\section{Method}

\section{Participants}

The sample consisted of 370 Elementary and Middle School students, and out of these 370 participants, 65 (17.6\%) were diagnosed with dyslexia, 132 (35.7\%) with ADHD, and 173 (46.8\%) had no school disabilities; $65.4 \%(n=242)$ were female and $34.6 \%(n=128)$ were male. Students with cognitive and/or sensory impairment were excluded. The evaluated students (age 7 - 16 years) were attending 2nd - 9th grades. Table 1 shows the distribution of the total sample and groups across grades.

\section{Instruments}

Rey Complex Figure Test (Rey, 2010). This instrument is restricted to licensed psychologists and is composed of two figures $1 \mathrm{~A}$ and $\mathrm{B}$; it is used to assess the perceptual and visual memory functions. In the present study, only figure A for individuals $5-88$ years was used. The test procedure consists of the copy of one of the figures, followed by immediate memory recall. It is worth highlighting that this instrument is for the use of psychologists only, according to Resolution $n^{\circ}$ 02/2003 of the Federal Council of Psychology.

The Thinking Styles Inventory-Revised II (TSI-R2) (Sternberg, Wagner, \& Zhang, 2007) evaluates 13 intellectual styles and consists of 65 items scored on a seven-point Likert scale; the score can range from 5 to 35 points. Students are asked to read each item and choose the answer that best describes their behavior (decide how well the statement fits the way that they typically do things), for example, item 5 "When faced with a problem, I use my own ideas and strategies to solve it; answers 
Table 1

Distribution of the total sample and the groups with dyslexia, Attention Deficit Hyperactivity Disorder (ADHD), and without learning disabilities across grades

\begin{tabular}{|c|c|c|c|c|c|c|c|c|}
\hline \multirow[t]{2}{*}{ School grade } & \multicolumn{2}{|c|}{$\begin{array}{l}\text { Total Sample } \\
\qquad(N=370)\end{array}$} & \multicolumn{2}{|c|}{$\begin{array}{l}\text { Dyslexia } \\
(n=65)\end{array}$} & \multicolumn{2}{|c|}{$\begin{array}{c}\text { ADHD } \\
(n=132)\end{array}$} & \multicolumn{2}{|c|}{$\begin{array}{l}\text { Without learning disability } \\
\qquad(n=173)\end{array}$} \\
\hline & $F$ & $\%$ & $F$ & $\%$ & $F$ & $\%$ & $F$ & $\%$ \\
\hline 2nd & 27 & 7.3 & 2 & 3.1 & 10 & 7.6 & 15 & 8.7 \\
\hline $3 r d$ & 51 & 13.8 & 10 & 15.4 & 22 & 16.7 & 19 & 11.0 \\
\hline 4th & 40 & 10.8 & 11 & 16.9 & 7 & 5.3 & 22 & 12.7 \\
\hline 5th & 49 & 13.2 & 8 & 12.3 & 15 & 11.4 & 26 & 15.0 \\
\hline 6th & 52 & 14.1 & 7 & 10.8 & 24 & 18.2 & 21 & 12.1 \\
\hline 7th & 58 & 15.7 & 9 & 13.8 & 28 & 21.2 & 21 & 12.1 \\
\hline 8th & 50 & 13.5 & 9 & 13.8 & 18 & 13.6 & 23 & 13.3 \\
\hline 9th & 43 & 11.6 & 9 & 13.8 & 8 & 6.1 & 26 & 15.0 \\
\hline Total & 370 & 100.0 & 65 & 100.0 & 132 & 100.0 & 173 & 100.0 \\
\hline
\end{tabular}

Note: F: Frequency.

range from: 1 (no at all well), 2 (not very well), 3 (slightly well), 4 (somewhat well) 5 (well), 6 (very well) and 7 (extremely well). This instrument can be administered individually or collectively; its validity in Brazil is measured.

\section{Procedures}

Data were collected from 55 public schools; 3 located in the city of Rolândia, 13 in Cambé, and 39 in Londrina, in the state of Paraná (PR), Brazil. The Núcleo Regional de Educação (Education Regional Center) and the Secretarias Municipais de Educação (Municipal Department of Education) were contacted to request a list of students with dyslexia and ADHD enrolled in public schools in Londrina and region. Subsequently, the evaluation of the students with dyslexia and ADHD (placed in Multifunctional Resource Rooms) and those without learning disabilities (placed in Regular Classrooms), was scheduled. The students without learning disabilities were selected by the teachers according to their academic performance. Three municipal and state schools were asked to select around 10 students per grade; only those who provided the Informed Consent form signed by their parents or guardians were evaluated. The reason for such a great number of schools is due to the fact that it was not easy to find students with these diagnoses.
The instruments were administered as follows: Rey Complex Figure Test was administered first, followed by TSI-R2. The inventory was read by the researcher in order to facilitate the understanding by students placed in Multifunctional Resource Rooms and by 2 nd - 5th grade students placed in Regular Classrooms. The instruments were administered individually, and the average administration time was 50 minutes. The instruments were administered during the regular class period to the students in Regular Classrooms and during the period when pedagogical assistance was provided to the students placed in Multifunctional Resource Rooms.

Data were entered into an Excel spreadsheet and were subjected to statistical analysis using the IBM Statistical Package for the Social Sciences (SPSS Inc., Chicago, Illinois, United States) Statistics for Windows ${ }^{\circledR}$, version 22. Descriptive statistics (mean and standard deviation) was used followed by parametric inferential tests (Analysis of Variance [ANOVA], post-hoc Tukey Honest Significant Difference (HSD) Test, and Pearson correlation coefficient) for comparison between the groups considering a significance level of $5 \%(p<0.05)$. The present study was approved by the Ethics Committee of the Universidade Estadual de Londrina, Protocol n 854.426/2014, Resolution $n^{\circ} 466 / 12$ (and complementary resolutions) passed by the National Health Council (Ministério da Saúde, 2012). 


\section{Results}

The copy and memory scores of the Rey Complex Figure Test were analyzed using descriptive and inferential statistics. Table 2 shows the mean scores, standard deviation, and the statistically significant differences between the groups.

The data presented in Table 2 show that students without learning disabilities had a significantly higher performance than the other students on both copy (Mean $-M=30.87$, Standard Deviation $-S D=3.83)$, and memory $(M=17.78$, $S D=6.16)$ conditions. The ANOVA revealed significant difference between the groups in the copy $(F(2,367)=28.659$ and $p=0.012)$ and memory $(F(2,367)=4.487, p=0.012)$ conditions. The post-hoc Tukey HSD Test showed significant difference only in the memory scores between the groups with ADHD and without learning disabilities $(p=0.002)$.

Descriptive and inferential statistics of the data of the TSI-R2 demonstrated the scores of the groups in the different types of intellectual styles. Table 3 shows the mean and standard deviation of the scores.

The Analysis of Variance analysis revealed significant differences between the groups in the following thinking styles: executive $(F(2,367)=$ $4.973, p=0.007)$, judicial $(F(2,367)=14.278$, $p<0.001)$, global $(F(2,367)=3.655, p=0,027)$, local $F(2,367)=14.425, p<0.001$, hierarchical
$(F(2,367)=16.500, p<0.001)$, oligarchic $(F(2$, $367)=3.379, p=0.035)$, and anarchic $(F(2,367)$ $=4.018, p=0.019)$. The post-hoc Tukey HSD Test showed significant differences between the groups with Dyslexia and without learning disabilities; the group without learning disabilities had significantly higher performance. Significant differences were also observed between the groups with ADHD and without learning disabilities; the students without school disabilities had significantly lower performance only on the oligarchic style $(M=21.02$, $S D=7.43 ; p=0.050)$. There was a significant difference between the groups with Dyslexia and ADHD only in hierarchical style $(p=0.049)$; the groups with dyslexia had a significantly lower performance $(M=14.92, S D=6.45)$ than the group with $\operatorname{ADHD}(M=17.46, S D=7.95)$.

Pearson correlation was used to analyze the association between the instruments used. Table 4 shows the statistically significant $(p<0.001)$ correlations between the Rey Complex Figure Test and the TSI-R2.

For the copy condition of the Rey Complex Figure Test, the analysis carried out showed the highest positive significant correlation with the judicial thinking style $(r=0.244 ; p<0.001)$, a negative significant correlation with the conservative style $(r=-0.241, p<0.001)$. For the memory condition, there was a negative significant correlation only with the conservative style $(r=-0.209, p<0.001)$. The data obtained are discussed below.

Table 2

Mean scores, standard deviation, and statistically significant differences between students with dyslexia, Attention Deficit Hyperactivity Disorder $(A D H D)$, and without learning disabilities in the Rey Complex Figure Test

\begin{tabular}{|c|c|c|c|c|c|c|}
\hline & \multirow{2}{*}{ Conditions } & \multicolumn{2}{|c|}{ Dyslexia $(n=65)$} & \multicolumn{2}{|c|}{ Without learning disability $(n=173)$} & \multirow{2}{*}{$p$} \\
\hline & & $M$ & $S D$ & $M$ & $S D$ & \\
\hline in & Copy & 26.69 & 6.21 & 30.87 & 3.83 & 0.001 \\
\hline \multirow{4}{*}{ 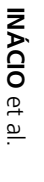 } & Memory & 16.83 & 7.21 & 17.78 & 6.16 & 0.310 \\
\hline & Conditions & \multicolumn{2}{|c|}{$A D H D(n=132)$} & \multicolumn{2}{|c|}{ Without learning disability $(n=173)$} & \multirow{2}{*}{$p$} \\
\hline & cumutiotis & $M$ & $S D$ & $M$ & $S D$ & \\
\hline & Copy & 26.88 & 5.99 & 30.87 & 3.83 & 0.001 \\
\hline & Memory & 15.56 & 6.31 & 17.78 & 6.16 & 0.002 \\
\hline
\end{tabular}


Table 3

Mean scores, standard deviation, and statistically significant differences between students with dyslexia, Attention Deficit Hyperactivity Disorder $(A D H D)$, and without learning disabilities in the Thinking Styles Inventory-Revised II

\begin{tabular}{|c|c|c|c|c|c|}
\hline \multirow{2}{*}{ Subscales } & \multicolumn{2}{|c|}{ Dyslexia $(n=65)$} & \multicolumn{2}{|c|}{ Without learning disability $(n=173)$} & \multirow[t]{2}{*}{$p$} \\
\hline & $M$ & $S D$ & M & $S D$ & \\
\hline Judicial & 18.66 & 7.82 & 22.56 & 6.47 & 0.001 \\
\hline Global & 16.06 & 7.65 & 18.68 & 6.29 & 0.026 \\
\hline Local & 15.49 & 6.56 & 20.48 & 6.11 & 0.001 \\
\hline Hierarchical & 14.92 & 6.45 & 20.51 & 6.66 & 0.001 \\
\hline Anarchic & 19.00 & 4.19 & 21.02 & 5.25 & 0.014 \\
\hline \multirow{2}{*}{ Subscales } & \multicolumn{2}{|c|}{$A D H D(n=132)$} & \multicolumn{2}{|c|}{ Without learning disability $(n=173)$} & \multirow[t]{2}{*}{$p$} \\
\hline & M & $S D$ & $M$ & $S D$ & \\
\hline Executive & 22.68 & 4.86 & 24.43 & 5.65 & 0.012 \\
\hline Judicial & 18.55 & 7.59 & 22.56 & 6.47 & 0.001 \\
\hline Local & 17.70 & 7.80 & 20.48 & 6.11 & 0.001 \\
\hline Hierarchical & 17.46 & 7.95 & 20.51 & 6.66 & 0.001 \\
\hline Oligarchic & 23.28 & 9.22 & 21.02 & 7.43 & 0.050 \\
\hline \multirow{2}{*}{ Subscales } & \multicolumn{2}{|c|}{ Dyslexia $(n=65)$} & \multicolumn{2}{|c|}{$A D H D(n=132)$} & \multirow{2}{*}{$p$} \\
\hline & $M$ & $S D$ & $M$ & $S D$ & \\
\hline Hierarchical & 14.92 & 6.45 & 17.46 & 7.95 & 0.049 \\
\hline
\end{tabular}

Note: M: Mean; SD: Standard Deviation; p: significance level.

Table 4

Statistically significant correlations between the Rey Complex Figure Test and the Thinking Styles Inventory-Revised II

\begin{tabular}{lcc}
\hline \multirow{2}{*}{ Categories } & \multicolumn{2}{c}{$r$} \\
\cline { 2 - 3 } & Copy & Memory \\
\hline Judicial & 0.244 & \\
Global & 0.180 & \\
Conservative & -0.241 & -0.209 \\
Hierarchical & 0.182 & \\
\hline
\end{tabular}

Note: $r$ : Pearson correlation coefficient. $p$ : significance level for all associations.

\section{Discussion}

The data were analyzed according to the performance and differences between the groups and the correlation between the instruments. With regard to the students' scores in the Rey Complex Figure Test, it was found that students without school disabilities had a significantly higher performance both on copy and memory conditions, as compared to the other groups. Some studies (Duranovic et al., 2015; Vélez-Van-Meerbeke et al., 2013) evaluated elementary and middle school students and found that students with dyslexia and ADHD had lower performance on the memory condition than the control group.

In the memory condition, the group without learning disabilities had a significantly higher performance than the group with ADHD. This finding is consistent with those of Borkowska et al. (2011) and Vélez-Van-Meerbeke et al. (2013). In contrast, Mesquita et al. (2010) did not find significant differences between the ADHD and control groups.

There were no significant differences in memory between the groups of students with dyslexia and without learning disabilities. These results are in agreement with those reported by Brunswick et al. (2010), Cruz-Rodrigues et al. (2014), and McManus et al. (2010). There were no significant differences between the groups with dyslexia and ADHD either, but some studies have reported changes in immediate memory recall in students with these disorders (Borkowska et al., 2011; Duranovic et al., 2015; Vélez-Van-Meerbeke et al., 2013). 
As for the copy condition, there were significant differences between the groups with dyslexia and without learning disabilities. These results differ from those of other studies (Brunswick et al., 2010; Cruz-Rodrigues et al., 2014; Duranovic et al., 2015; McManus et al., 2010), which reported similar performance between dyslexic students and the control group. The significant differences between students with ADHD and without learning disabilities corroborated the findings of VélezVan-Meerbeke et al. (2013), who found deficits in the copy condition. However, Mesquita et al. (2010) and Borkowska et al. (2011) did not find differences between the group with ADHD and the control group. It is worth mentioning that, in the present study, the mean scores of the groups with dyslexia and ADHD were similar, and there were no significant differences.

In this analysis of the TSI-R2, the students without school disabilities had significantly higher performance than the diagnosed groups on almost all intellectual styles, except for the oligarchic style, in which the group with ADHD had a significantly higher performance. This result refers to lower performance on the type III style. According to Zhang (2002) and Grigorenko and Sternberg (1995), students with high cognitive and academic performances tend to use more styles, especially Type I styles.

Significant differences were also found comparing the groups with dyslexia, ADHD, and without learning difficulties. Comparison between the groups with dyslexia and without learning disabilities revealed significant differences in the judicial, global, local, hierarchical, and anarchic thinking styles. Some studies have reported that the hierarchical and local styles can contribute to academic performance, the hierarchical and anarchical styles can contribute to the organization of thought, and the legislative, judicial, and liberal styles are associated with high intellectual capacity (John et al., 2011; Martínez \& Brufau, 2010; Grigorenko \& Sternberg, 1995).

There were significant differences in the executive, judicial, local, hierarchical, and oligarchic thinking styles between students with ADHD and without learning disabilities. Some studies have pointed to the fact that unlike the executive, conservative, local, monarchic thinking styles, the legislative, judicial, global, hierarchical, and liberal styles are related to learning development (Zhang, 2010, 2015).

Comparison between the groups with Dyslexia and ADHD revealed significant differences only in the hierarchical thinking style; students with ADHD had significantly higher performance than that of the students with dyslexia. Despite these differences, the performance of both groups is significantly lower than that of the group without learning disabilities, which may indicate that the similarity in the information processing profile results from the changes in cognitive functions (Cypel, 2016; Fletcher et al., 2009; Guardiola, 2016; Kaefer, 2016; Pisacco et al., 2016; Moojen \& França, 2016; Rotta \& Pedroso, 2016). Considering the $p$-value found ( $p=0.049$ ), further research is needed to confirm the differences between the groups.

Testing the correlation between the instruments, it was found that the copy condition of the Rey Complex Figure Test was correlated with the Type I thinking styles (judicial, global, and hierarchical) and the type II conservative style. In the latter, the copy score increase was associated with the decrease in the use of this type of style and vice versa. Doménech-Betoret and Gómez-Artiga (2014) and Zhang (2015) have proved the superiority of Type I styles over Type II thinking styles. Thus, these data demonstrate the relationship between perception and the styles that are more closely involved with an effective learning process.

With regard to the memory condition, there was correlation only with the conservative style. Such correlation indicated that the memory score increase was associated with the decrease in the use of this thinking style and vice versa. This result, like what was found for perception, is consistent with that reported in other studies because the conservative thinking style is a type II style. Doménech-Betoret and Gómez-Artiga (2014) and Zhang (2015) demonstrated the superiority of Type I styles over Type II styles. Moreover, the 
findings of Zhang (2010) showed that Type II styles, especially the monarchic and conservative styles, do not contribute to the psychosocial development.

The finding that students with dyslexia and ADHD had lower scores than students without learning disabilities on almost all items of the instruments used may be related to cognitive deficits. The results showed low performance of students with these diagnoses on the memory condition which can affect information processing. Thus, there is a need for interventions to improve memory, especially in the ADHD group. In addition, in TSI-R2, the dyslexic and ADHD students had significantly lower performance on Type I thinking styles (judicial, global, and hierarchical) and higher performance on the oligarchic type III style than those without learning disabilities. This shows the need to invest in studies on the development of Type I thinking styles (especially the hierarchical style), mainly in the group with dyslexia, aiming at an effective learning process.

The present study has some limitations. One of them is the fact that international and/or national studies investigating intellectual styles in students with dyslexia and ADHD were not found in the literature. Furthermore, the students' socioeconomic status should have been properly managed during the formation of the control group (children without disabilities). Therefore, studies exploring the affective variables related to motivation that could provide additional explanations are needed; in addition, further experimental studies could analyze the effectiveness of memory training and training for development of intellectual styles and verify whether the correlation between the variables would be affected. The Thinking Styles Inventory proved to be a reliable and valid instrument since the groups compared differed in their thinking styles, as expected.

Finally, an aspect that deserves comment is the lack of policies on the education of students with learning disabilities and/or attention deficit. These students are placed in Multifunctional Resource Rooms for specialized instruction and academic remediation, but they are not properly evaluated by a multidisciplinary team. Thus, the diagnosis is inconclusive, and the activities carried out with these students lack planning. There has been an increased number of diagnoses of these types of disorders, which leads one to assume that some learning disabilities which could be overcome with appropriate pedagogical practices are not receiving the attention they deserve. Therefore, studies are required to better understand the learning process of these students.

\section{Contributors}

All authors participated in all phases of the research article.

\section{References}

Alves, L. M., \& Ribeiro, M. M. (2011). Desempenho em memória de trabalho em escolares com e sem queixas de alterações de aprendizagem. Revista Tecer, 4(6), 54-65. https://www.doi.org/10.15601/1983-7631/ rt.v4n6p54-65

American Psychiatric Association. (2014). Manual diagnóstico e estatístico de transtornos mentais: DSM-5 (5a ed.). Porto Alegre: Artmed.

Baddeley, A. D., \& Hitch, G. J. (1974). Working memory. In G. BOWER (ed.), The psychology of learning and motivation. New York: Academic Press.

Borkowska, A. R., Słopień, A., Pytlińska, N., Rajewski, A., Dmitrzak-Weglarz, M., Szczepankiewicz, A., \& Wolańiczyk, T. (2011). Visual-spatial functions and organisation of grapho-motor actions in ADHD children. Psychiatria Polska, 45(3), 367-378. Retrived February, 11, 2016, from http://www.ncbi.nlm.nih. gov/pubmed/22232967

Brunswick, N., Martin, G. N., \& Marzano, L. (2010). Visuospatial superiority in developmental dyslexia: Myth or reality? Learning and Individual Differences, 20(5), 421-426. https://www.doi.org/10.1016/j.lindif. 2010.04.007

Bzuneck, J. A., \& Guimarães, S. E. R. (2010). Aprendizagem escolar em contextos competitivos. In E. Boruchovitch, \& J. A. Bzuneck (Orgs.), Aprendizagem: processos psicológicos e o contexto social na escola (2a ed.). Petrópolis: Vozes.

Carvalho, M. C., Lima, R. F., Souza, G. G. B., Pires, T. C., Pierini, R., Rodrigues, S. das D., ... Ciasca, S. M. (2016). Characterization of school-related problems and diagnoses in a Neuro-Learning Disorder Clinic. Estudos de Psicologia (Campinas), 33(1), 161-171 https:// www.doi.org/10.1590/1982-027520160001000016 
Cruz-Rodrigues, C., Barbosa, T., Toledo-Piza, C. M. J., Miranda, M. C., \& Bueno, O. F. A. (2014). Neuropsychological characteristics of dyslexic children. Psicologia: Reflexão e Crítica, 27(3), 539-546. https:// www.doi.org/10.1590/1678-7153.201427315

Cypel, S. (2016). Funções executivas: seu processo de estruturação e a participação no processo de aprendizagem. In N. T. Rotta, L. Ohlweiler, \& R. S. Riesgo (Orgs.), Transtornos da aprendizagem: abordagem neurobiológica e multidisciplinar (2a ed.). Porto Alegre: Artmed.

Doménech-Betoret, F., \& Gómez-Artiga, A. (2014). The relationship among students' and teachers' thinking styles, psychological needs and motivation. Learning and Individual Differences, 29, 89-97. https://www. doi.org/10.1016/j.lindif.2013.10.002

Duranovic, M., Dedeic, M., \& Gavrić, M. (2015). Dyslexia and visual-spatial talents. Current Psychology, 34, 207-222. https://www.doi.org/10.1007/s12144-01 4-9252-3

Fan, J., \& Zhang, L. F. (2014). The role of perceived parenting styles in thinking styles. Learning and Individual Differences, 32, 204-211. https://www.doi. org/10.1016/j.lindif.2014.03.004

Fletcher, J. M., Lyons, G. R., Fuchs, L. S., \& Barnes, M. A. (2009). Transtornos de leitura: reconhecimento das palavras. In J. M. Fletcher, G. R. Lyons, L. S. Fuchs, \& M. A. Barnes, Transtornos de aprendizagem: da identificação à intervenção. Porto Alegre: Artmed.

Grigorenko, E. L., \& Sternberg, R. J. (1995). Thinking styles. In D. Saklofske \& M. Zeidner (Eds.), International handbook of personality and intelligence. New York: Plenum Press.

Guardiola, A. (2016). Transtorno de atenção: aspectos neurobiológicos. In N. T. Rotta, L. Ohlweiler, \& R. S. Riesgo (Orgs.), Transtornos da aprendizagem: abordagem neurobiológica e multidisciplinar (2a ed.). Porto Alegre: Artmed.

Hall, D., Jarrold, C., Towse, J. N., \& Zarandi, A. L. (2015). The developmental influence of primary memory capacity on working memory and academic achievement. Developmental Psychology, 51(8), 1131-1147. https:// www.doi.org/10.1037/a0039464

IBM Corporation. (2013). IBM SPSS Statistics for Windows: version 22.0. New York: Author.

John, S. V., Singh, B. G., \& Verma, O. P. (2011). Thinking styles and academic performance among tribal and non-tribal students. Psychological Studies, 56(2), 220-231. https://www.doi.org/10.1007/s12646-011-0 $076-z$

Kaefer, H. (2016). Avaliação psicológica no transtorno da atenção. In N. T. Rotta, L. Ohlweiler, \& R. S. Riesgo (Orgs.), Transtornos da aprendizagem: abordagem neurobiológica e multidisciplinar (2a ed.). Porto
Litzinger, T. A., Ha Lee, S., Wise, J. C., \& Felder, R. M. (2007). A psychometric study of the index of learning styles. Journal of Engineering Education, 96(4), 309-319. https://www.doi.org/10.1002/j.2168-9830.2007.tb0 0941.x

Martínez, O. L., \& Brufau, R. M. (2010). Estilos de pensamiento y creatividad. Anales de Psicologia, 26(2), 254-258. Recuperado em fevereiro, 11, 2016, de http://www.redalyc.org/articulo.oa?id=16713079008

McManus, I. C., Chamberlain, R., Loo, P. W., Riley, H., Rankin, Q., \& Brunswick, N. (2010). Art students who cannot draw: Exploring the relations between drawing ability, visual memory, accuracy of copying, and dyslexia. Psychology of Aesthetics, Creativity, and the Arts, 4(1), 18-30. https://www.doi.org/10.1037/ a0017335

Menezes, A., Godoy, S., \& Seabra, A. G. (2009). Avaliação da memória de trabalho em alunos de $5^{\mathrm{a}}$ a $8^{\mathrm{a}}$ série do ensino fundamental. Psicologia: Teoria e Prática, 11(3), 16-26. Recuperado em fevereiro, 11, 2016, de http://pepsic.bvsalud.org/scielo.php?script=sci_ arttext\&pid=S1516-36872009000300003

Mesquita, C., Coutinho, G., \& Mattos, P. (2010). Perfil neuropsicológico de adultos com queixas de desatenção: diferenças entre portadores de TDAH e controles clínicos. Revista de Psiquiatria Clínica, 37(5), 212-225. https://www.doi.org/10.1590/S0101-60 832010000500005

Ministério da Saúde (Brasil). (2012). Resolução n 466, de 12 de dezembro de 2012. Aprova as diretrizes e normas regulamentadoras de pesquisas envolvendo seres humanos. Diário Oficial da União, n 112, jun. 2013, Seção 1, p.59-62.

Moojen, S., \& Costa, A. C. (2016). Semiologia psicopedagógica. In N. T. Rotta, L. Ohlweiler, \& R. S. Riesgo (Orgs.), Transtornos da aprendizagem: abordagem neurobiológica e multidisciplinar ( 2 a ed.). Porto Alegre: Artmed.

Moojen, S., \& França, M. (2016). Dislexia: visão fonoaudiológica e psicopedagógica. In N. T. Rotta, L. Ohlweiler, \& R. S. Riesgo (Orgs.), Transtornos da aprendizagem: abordagem neurobiológica e multidisciplinar (2a ed.). Porto Alegre: Artmed.

Ohlweiler, L. (2016). Introdução aos transtornos da aprendizagem. In N. T. Rotta, L. Ohlweiler, \& R. S. Riesgo (Orgs.), Transtornos da aprendizagem: abordagem neurobiológica e multidisciplinar (2a ed.). Porto Alegre: Artmed.

Pisacco, N. M. T., Sperafico, Y. L. S., Costa, A. C., \& Dorneles, B. V. (2016). Intervenções escolares em alunos com Transtorno de Déficit de Atenção/ Hiperatividade. In N. T. Rotta, L. Ohlweiler, \& R. S. Riesgo (Orgs.), Transtornos da aprendizagem: abordagem neurobiológica e multidisciplinar (2a ed.). Porto Alegre: Artmed. 
Rey, A. (2010). Figuras complexas de Rey: teste de cópia e de reprodução de memória de figuras geométricas complexas. São Paulo: Casa do Psicólogo.

Riesgo, R. S. (2016). Transtorno da memória. In N. T. Rotta, L. Ohlweiler, \& R. S. Riesgo (Orgs.), Transtornos da aprendizagem: abordagem neurobiológica e multidisciplinar (2a ed.). Porto Alegre: Artmed.

Rotta, N. T. (2016). Dificuldades para aprendizagem. In N. T. Rotta, L. Ohlweiler, \& R. S. Riesgo (Orgs.), Transtornos da aprendizagem: abordagem neurobiológica e multidisciplinar (2a ed.). Porto Alegre: Artmed.

Rotta, N. T., \& Pedroso, F. S. (2016). Transtorno da Linguagem Escrita: dislexia. In N. T. Rotta, L. Ohlweiler, \& R. S. Riesgo (Orgs.), Transtornos da aprendizagem: abordagem neurobiológica e multidisciplinar (2a ed.). Porto Alegre: Artmed.

Sternberg, R. J. (2010). Psicologia cognitiva. Porto Alegre: Artes Médicas.

Sternberg, R. J., Wagner, R. K., \& Zhang, L. F. (2007). Thinking Styles Inventory: Revised II (TSI-R2). Medford, MA: Tufts University.

Vélez-Van-Meerbeke, A., Zamora, I. P., Guzmán, G., Figueroa, B., López-Cabra, C.A., \& Talero-Gutiérrez, C. (2013). Evaluación de la función ejecutiva en una población escolar consíntomas de déficit de atención e hiperactividad. Neurología, 28(6), 348-355. https:// www.doi.org/10.1016/j.nrl.2012.06.011

Zhang, L. F. (2002). Thinking styles and cognitive development. The Journal of Genetic Psychology, 163(2),
179-195. https://www. doi.org/10.1080/00221320 209598676

Zhang, L. F. (2010). Further investigating thinking styles and psychosocial development in the Chinese higher education context. Learning and Individual Differences, 20, 593-603. https://www. doi.org/10.1016/j.lindif. 2010.04.011

Zhang, L. F. (2013). The malleability of intellectual styles. New York: University Press.

Zhang, L. F. (2015). Fostering successful intellectual styles for creativity. Asia Pacific Education Review, 16, 183-192. https://www. doi.org/10.1007/s12564-0 15-9378-5

Zhang, L. F., \& Sternberg, R. J. (2005). A threefold model of intellectual styles. Educational Psychology Review, 17(1), 1-53. https://www.doi.org/10.1007/s10648-0 05-1635-4

Zhang, L. F., \& Sternberg, R. J. (2006). The nature of intellectual styles. New Jersey: Lawrence Erlbaum Associates.

Zhang, L. F., \& Sternberg, R. J., \& Rayner, S. (2011). Intellectual Styles: Challenges, milestones, and agenda. In L. F. Zhang, R. J. Sternberg, \& S. Rayner. (Eds.), Handbook of intellectual styles: Preferences in cognition, learning, and thinking. New York: Springer Publishing Company.

Received: March 29, 2016

Final version: June 8, 2016

Approved: June 29, 2016 